\title{
Presentation of glioblastoma multiforme in young patients: a retrospective analysis from a regional cancer center of Northern India
}

D.K. Parida

\begin{abstract}
Abstrak
Glioblastoma multiforme (GBM) yang lazimnya terjadi pada usia dekade ke 5 dan ke 6, juga dapat mengenai pasien anak. Pembedahan masih merupakan cara penanganan yang utama. Namun, kira-kira $50 \%$ tumor yang mengenai batang otak merupakan glioblastoma multiforme, di mana hanya radioterapi yang bisa diberikan. Dalam tulisan ini dilaporkan analisa 11 penderita GBM antara tahun 1992-1996. Usia penderita berkisar antara 6 bulan sampai 15 tahun. Sembilan penderita telah mengalamioperasi. Delapan penderita mendapat radioterapi pasca bedah, dan delapan lainnya mendapat kemoterapi. Lamanya follow-up berkisar antara $2-24$ bulan dengan median 10,5 bulan. Pada waktu evaluasi, lima penderita tidak menunjukkan tanda-tanda sakit, tiga penderita dengan status penyakit yang stabil dan dua dengan penyakit progresif. Dapat disimpulkan bahwa pendekatan terapi multimodal memberikan hasil yang lebih baik dibandingkan dengan terapi tunggal dan pasien dengan tingkat penyakit yang masih dapat dioperasi menunjukkan waktu bebas penyakit yang lebih panjang.
\end{abstract}

\begin{abstract}
Glioblastoma multiforme (GBM) though commonly occurs in fifth to sixth decade of life, also found in paediatric patients. Surgery remains the mainstay of the management. However around 50\% of the brainstem space occupying lesions are glioblastoma multiforme, where radiotherapy is the only therapeutic modality to be offered. We analysed IJ patients of GBM between 1992 to 1996. The age of the patients were between 6 months and 15 years. Nine patients had undergone surgery, eight patients were treated with post-operative radiotherapy and eight patients had received chemotherapy. The follow up period ranged from 2-24 months with a median of 10.5 months. At the time of analysis five patients were without any evidence of disease, there had stable and two patients had progressive disease. It may be concluded that multimodal therapeutic approach offered a better disease control than single modality and the surgically operable group showed a prolonged disease free survival.
\end{abstract}

Keywords: Glioblastoma multiforme, radiotherapy, chemotherapy, brain tumor

Brain tumors are the most common solid malignancies occuring in children. Out of all cancers, brain tumors are second to leukemia in young patients. Glioblastoma multiforme (GBM) though not common in children, accounts for $11 \%$ of them. 'The mean age for GBM is around 54 years with a male predilection. The management of GBM in pediatric patients is a challenge for the neurosurgeon, radiotherapist as well as pediatric oncologist. To achieve tumor control at the cost of growing brain is a very critical equation. In spite of the combination of various therapeutic modalities, the outcome has not changed significantly over the period of time. However with the advent of technological innovations, improved neurosurgical techniques

Department of Radiotherapy,

All India Institute of Medical Sciences, New Delhi-110029, India combined with newer anaesthetic approach and stereotactic radiotherapy, the quality of life and disease free survival have definitely changed.

\section{METHODS}

This analysis was carried out with an aim to know the exact incidence of GBM occuring in young patients, their prognostic factors and clinical course. A total of 11 patients were analysed from January 1992 till December 1996. All the patients had histopathological proof of GBM. All the patients were evaluated in a combined pediatric cancer clinic and they were seen by neurosurgeon, radiotherapist and pediatric oncologist. All the patients were subjected to CT scan or MRI of the brain along with other routine investigations. In selected cases, magnetic resonance spectroscopy was performed. Their performance status and 
neurological status were recorded very carefully. Simultaneously, pre-anaesthetic check-up were also done. Our institutional policy is to deliver $50 \mathrm{~Gy}$ in 28-30 fractions to the whole brain followed by boost to the tumor bed with a margin of $3 \mathrm{~cm}$ till $66 \mathrm{~Gy}$. Medical decompression was done whenever required. Only two patients could tolerate the full course of radiotherapy. Five patients received a dose between 40-60 Gy and one patient received $36 \mathrm{~Gy}$. Chemotherapy was a part of the treatment protocol. Eight patients received chemotherapy following surgery and radiotherapy. The cycles consisted of either or combination of cisplatinum $\left(100 \mathrm{mg} / \mathrm{m}^{2}, \mathrm{Dl}\right)$, etoposide $\left(100 \mathrm{mg} / \mathrm{m}^{2}, \mathrm{D} 1-3\right)$, vincristine $\left(1.2 \mathrm{mg} / \mathrm{m}^{2}\right.$, D1) and CCNU $\left(120 \mathrm{mg} / \mathrm{m}^{2}\right)$ repeated after 3 weeks. A minimum of three cycles were instituted. At the end the patients were followed up at an interval of six weeks for the first year, 2 months for second year and 3 months there after. Change of performance status and symptoms were carefully noted during follow up visits. Imaging. studies were performed at an interval of six months or whenever required.

\section{RESULTS}

The age of the patients varied from 6 months to 15 years. Majority of the patients were between 10-15 years of age. The youngest patient was of 6 months of age at the time of diagnosis. There was only one female patient in this series. The most common anatomical sites were temporal (4), parieto occipital (3), brain stem (2) followed by temporoparietal (1) and fourth ventricle (1). Majority of the patients in this series presented with the symptoms of vomiting, headache, seizures. Three patients complained of weakness in their extremities and one presented with double vision. All these features are elaborated in table 1 . In this series nine patients had undergone surgical decompression and two had only biopsy. VP shunt was given in five patients. Eight patients had received post operative radiotherapy which was delivered by tele-cobalt unit with parallel opposed port. The detailed treatment profile is given in table 2 . The radiotherapy dose ranged from 36-66 Gy (Table 3). The follow up period ranged between 2-24 months with a median of 10.5 months. At the time of analysis two patients were lost to follow up. Out of nine evaluable patients, five patients were without any disease and rest of the patients were having disease out of whom two patients were with progressive disease (Table 4).
Table 1. Pre-treatment patient characteristic

\begin{tabular}{lc}
\hline Characteristics & No of patients \\
\hline Age (years) & 1 \\
$<2$ & 4 \\
$2-10$ & 6 \\
$10-15$ & \\
KPS & 4 \\
$>90$ & 5 \\
$50-90$ & 2 \\
$<50$ & \\
Site of the primary disease & 4 \\
Temporal & 3 \\
Parieto-occipital & 2 \\
Brainstem & 1 \\
Temporoparietal & 1 \\
4th ventricle & \\
Post-op residual disease status & \\
Macroscopic & 5 \\
Microscopic & 6 \\
Presenting symptoms & \\
Headache & \\
Vomiting & 9 \\
Seizure & 7 \\
Paresis & \\
Blurred vision & \\
\hline
\end{tabular}

Table 2. Treatment profile

\begin{tabular}{lc}
\hline Treatment modality & No. of patients \\
\hline Surgery & 9 \\
Radiotherapy & 8 \\
Chemotherapy & 6 \\
Only Biopsy & 2 \\
\hline
\end{tabular}

Table 3. Radiotherapy dose

\begin{tabular}{lc}
\hline RT Dose & No. of patients \\
\hline$>60 \mathrm{~Gy}$ & 4 \\
$40-60 \mathrm{~Gy}$ & 3 \\
$<40$ & 1 \\
\hline
\end{tabular}

Table 4. Follow-up details

\begin{tabular}{lc}
\hline Disease status & No. of patients \\
\hline No disease & 5 \\
Radiological evidence of stable disease & 3 \\
Progressive disease & 2 \\
Dead & 1 \\
\hline
\end{tabular}




\section{DISCUSSION}

GBM in paediatric patients pose a major challenge for the oncologist. Beside surgery, radiotherapy is the main adjuvant modality available for the management. ${ }^{2}$ Radiation planning is the sole most important aspect for the radiotherapist. At the time of planning it should be kept in mind that the brain of the child is in growing state and the child will not co-operate for positioning. Computerised tomographic (CT) scan is the major diagnostic tool for the investigation of childhood brain tumors. But it has got little limitations in case the tumor is close to the base of skull and in the brain stem, where magnetic resonance imaging (MRI) is a better option. Contrast enhancement studies give better sensitivity. Our experience shows that MRI has shown to be more effective and sensitive in demonstrating a greater anatomic details for the infiltrating type of tumors. The clinical symptoms depend on the anatomical location of the lesion and the age of the patient. GBM situated in the posterior fossa or cerebral hemisphere have a poor prognosis. A maximum survival rate of $20 \%$ can be expected in the children with these disease. ${ }^{2}$ Patients who undergo surgical debulking live longer than those without it. This difference actually depends on the amount of surgical resection. ${ }^{3,4,5}$ The role of chemotherapy in paediatric patients is still investigational. Recently one large trial of American Children's Cancer Study Group concluded that there was a marked survival advantage at 2 years and 5 years in the group who received CT in addition to surgery and radiotherapy. Randomised studies have established that addition of post operative radiotherapy prolong the survival. ${ }^{6}$ Albright et al have reported that most of the brainstem tumors are of highgrade nature. ${ }^{1}$ Surgery remains the mainstay of treatment. It helps to establish the diagnosis, tumor debulking improves the symptom and increases the sensitivity to other modalities of treatment leading to prolonged survival. Many retrospective studies have established the role of the extent of surgical debulking on the ultimate survival period. Prognostically it is the post-operative residual tumor volume which is important than the pre-operative volume. ${ }^{3,4,5}$ Some other prognostic factors like age Karnofsky Performance Scale (KPS), duration of symptoms and level of consciousness have already been established in adults. We have tried to corelate some of the features in our analysis. It was found that the younger the age of the patient, the less was the tolerance to various modalities of treatment. And in patients with good performance status, the response was better. The patients who presented with symptoms with shorter duration, tolerated the treatment better and also responded well.
Besides surgery, radiotherapy is an important adjuvant modality, ${ }^{2,7,8,9}$ but in case of brainstem GBM it is the only option. Brain Tumor Study Group (BTSG) has already proved that the whole brain irradiation with a total dose of 55-60 Gy increases the survival over surgery alone. All the patients in the study group received whole brain radiotherapy followed by boost to the tumor till $66 \mathrm{~Gy}$. It was observed that the patients who received higher dose, survived better. As the survival in these patients is limited, achieving tumor control becomes more important than the late effects of radiotherapy on brain. At the present time, with advent of newer technology, availability of better anaesthetic drugs, delivering radiotherapy to the brain of the young patients has become much easier. Some centers are also trying different protocols like hyperfractionation, interstitial brachytherapy and stereotactic radiotherapy along with or without radiosensitisers are being tried to improve upon the local control. The role of chemotherapy is still investigational. ${ }^{7,8}$ However, the study by the American Children's Cancer Study Group showed a survival advantage when given along with surgery and radiotherapy. Due to lack of therapeutic specificity, intrinsic cellular resistance, intolerance of normal tissues to drug toxicity, the role of chemotherapy in children has not shown much improvement in patient survival.

In conclusion the incidence of GBM in children is not so common. Due to less tolerance to various therapeutic modalities, limited survival and lack of proper randomised trials optimum combination of different modalities are not possible. The tumor behaves more aggressively than the adult ones. Surgery remains the mainstay of treatment and radiotherapy happens to be the main adjuvant therapy.

\section{REFERENCES}

1. Albright AL, Price RA, Guthkelch AN. Brainstem gliomas of children: a clinicopathological study. Cancer 1983;52: 2313-19.

2. Ammirati M, Vick N, Liao Y et al. Effect of the extent of surgical resection on survival and quality of life in patients with supratentorial GBM and anaplastic astrocytoma. Neurosurg 1987;21:201-6.

3. Devaux BC, O'Fallon JR, Kelly PJ. Resection, biopsy and survival in malignant glial neoplasms: a retrospective study of clinical parameters, therapy and outcome. J Neurosurg 1993;78:767-75.

4. Curran WJ Jr, Scott CB, Horton J et al. Does extent of surgery influence outcome for astrocytoma with atypical or anaplastic foci (AAF). A report from three Radiation Therapy Oncology Group (RTOG trials). J Neuro Oncol 1992;12:219-24. 
5. Simpson JR, Horton J, Scott $\mathrm{C}$ et al. Influence of location and extent of surgical resection on survival of patients with GBM: results of three consecutive Radiotherapy Oncology (RTOG) Clinical Trials. Int J Radioth Oncol Biol Phys 1993;26:239. Walker MD, Green SB, Petal BD. Randomised comparisons of radiotherapy and nitrosoureas for the treatment of malignant glioma after surgery NEJM 1980 303:1323-29.

6. Deutsch M, Green SB, Strike TA et al. Results of a randomised trial comparing BCNU plus Radiotherapy, streptozotocin plus radiotherapy, BCNU plus hyperfractionated radiotherapy and $\mathrm{BCNU}$ following misonidazole plus radiotherapy in the post operative treatment of malignant glioma. Int J Radioth Oncol Biol Phys 1989;16:1389-96.
7. Walker MD, Alexander E, Hunt WE et al. Evaluation of BCNU \&/or radiotherapy in the treatment of malignant glioma; a co-operative clinical trial. J Neurosurg 1978;49: 333-43.

8. Liv H, Davis R, Vestnys P, Resser K, Levin V. Correlation of survival and diagnosis in supratentorial malignant gliomas. J Neuro Oncol 1984;2;268-73.

9. Wood JR, Green SB, Shapiro WR. The prognostic importance of tumor size in malignant gliomas: a computed tomographic scan study by the brain Tumor Cooperative Group. J Clin Oncol 1988;6:338-45. 